\title{
Research Article \\ Effect of Solution Spray Rate on the Properties of Chemically Sprayed ZnO:In Thin Films
}

\author{
Merike Kriisa, ${ }^{1}$ Malle Krunks, ${ }^{1}$ Erki Kärber, ${ }^{1}$ Mart Kukk, ${ }^{1}$ Valdek Mikli, ${ }^{2}$ and Arvo Mere \\ ${ }^{1}$ Department of Materials Science, Tallinn University of Technology, Ehitajate Tee 5, 19086 Tallinn, Estonia \\ ${ }^{2}$ Centre for Materials Research, Tallinn University of Technology, Ehitajate Tee 5, 19086 Tallinn, Estonia
}

Correspondence should be addressed to Malle Krunks; malle.krunks@ttu.ee

Received 14 December 2012; Accepted 1 March 2013

Academic Editor: Jie-Fang Zhu

Copyright (C) 2013 Merike Kriisa et al. This is an open access article distributed under the Creative Commons Attribution License, which permits unrestricted use, distribution, and reproduction in any medium, provided the original work is properly cited.

\begin{abstract}
ZnO:In thin films were grown from $100 \mathrm{~mL}$ of spray solution on glass substrates by chemical spray at $T_{s}=400^{\circ} \mathrm{C}$ using solution spray rates of 0.5-6.7 mL/min. Zinc acetate and indium(III)chloride were used as $\mathrm{Zn}$ and $\mathrm{In}$ sources, respectively, with [In]/[Zn] $=3$ at.\%. Independent of solution spray rate, the crystallites in ZnO:In films grow preferentially in the (101) plane parallel to the substrate. The solution spray rate influences the surface morphology, grain size, film thickness, and electrical and optical properties. According to SEM and AFM studies, sharp-edged pyramidal grains and canvas-resembling surfaces are characteristic of films grown at spray rates of 0.5 and $3.3 \mathrm{~mL} / \mathrm{min}$, respectively. To obtain films with comparable film thickness and grain size, more spray solution should be used at low spray rates. The electrical resistivity of sprayed $\mathrm{ZnO}$ :In films is controlled by the solution spray rate. The carrier concentration increases from $2 \cdot 10^{19} \mathrm{~cm}^{-3}$ to $1 \cdot 10^{20} \mathrm{~cm}^{-3}$ when spray rate is increased from $0.5 \mathrm{~mL} / \mathrm{min}$ to $3.3 \mathrm{~mL} / \mathrm{min} \mathrm{independent}$ of the film thickness; the carrier mobilities are always lower in slowly grown films. Sprayed ZnO:In films transmit $75-80 \%$ of the visible light while the increase in solution spray rate from $0.5 \mathrm{~mL} / \mathrm{min}$ to $3.3 \mathrm{~mL} / \mathrm{min}$ decreases the transmittance in the NIR region and increases the band gap in accordance with the increase in carrier concentration. Lower carrier concentration in slowly sprayed films is likely due to the indium oxidation.
\end{abstract}

\section{Introduction}

The wide band gap zinc oxide can be used in many applications, for example, in piezoelectric transducers, as transparent conductive layers (TCO-s), and as window layers in photovoltaic devices [1]. Various methods such as atomic layer deposition (ALD) [2], pulsed laser deposition (PLD) [3], chemical bath deposition (CBD) [4], RF magnetron sputtering [5], and chemical spray pyrolysis (CSP) [3, 6-16] have been used to deposit $\mathrm{ZnO}$ thin films. Among these methods, the spray pyrolysis is a versatile and cost-effective method for the rapid production of large-area metal oxide thin films.

Up to date, the effect of several technological parameters (zinc source and concentration, dopant type and concentration, solvent, growth temperature, etc.) on the properties of sprayed $\mathrm{ZnO}$ films have been studied [6-16] to determine the optimal deposition conditions to obtain as high electrical conductivity and optical transparency as possible. Earlier studies have shown that the preferred crystallite orientation of intrinsic $\mathrm{ZnO}$ and gallium- and aluminium-doped $\mathrm{ZnO}$ is along $c$-axis $[8,9,15]$ while the preferred crystallite orientation of indium-doped $\mathrm{ZnO}$ film is (101) plane parallel to the substrate $[7-9,12,15]$. The use of $\mathrm{Ga}$ or $\mathrm{Al}$ as the dopant leads to smaller grains than the use of In as a dopant $[6,7$, 9]. Additionally, the density and the optical transmittance of sprayed $\mathrm{ZnO}$ film is controlled by the dopant type and concentration [7]. It has been reported that an optimal growth temperature for sprayed $\mathrm{ZnO}$ films is in the range of $350-500^{\circ} \mathrm{C}$. Independent of dopant, the optical transmittance is ca. $85 \%[7,9,17-19]$ while the lowest resistivities of sprayed indium-doped and gallium-doped $\mathrm{ZnO}$ thin films are in the order of $10^{-4}-10^{-3} \Omega \mathrm{cm}[17,18]$ and in the order of $10^{-3}-10^{-2} \Omega \mathrm{cm}$ for aluminium-doped $\mathrm{ZnO}$ [19].

Sprayed ZnO:In thin films have been used successfully as front electrodes in thin film silicon solar cells [20] and as window layer in $\mathrm{Cu}(\mathrm{In}, \mathrm{Ga})(\mathrm{S}, \mathrm{Se})$ solar cells [21]. Our longterm goal is to study the feasibility of ITO substitution with 
$\mathrm{ZnO}: \mathrm{In}$, for use as the front electrode in the CSP-prepared extremely thin inorganic absorber (ETA) solar cell [22].

Among mentioned technological parameters, the solution spray rate (or solution flow rate) and its effect on $\mathrm{ZnO}$ thin films have received little attention. Ebothé et al. [16] studied the effect of the solution flow rate on the growth of undoped $\mathrm{ZnO}$ films prepared from $\mathrm{ZnCl}_{2}$ solution and reported that the solution flow rate influences the surface topology. Dedova et al. [10] concluded that the solution spray rate affects the surface morphology and roughness of undoped $\mathrm{ZnO}$ thin films produced by spraying $\mathrm{Zn}$ acetate solutions.

Recently, we showed that the electrical resistivity of chemically sprayed In-doped $\mathrm{ZnO}$ thin films grown at $400^{\circ} \mathrm{C}$ can be altered within an interval of $10^{2}-10^{-3} \Omega \mathrm{cm}$ by varying the solution spray rate [12]. In this study we will not focus on obtaining the highest electrical conductivity or optical transmittance; we study the effect of the solution spray rate on the structural, morphological, optical, and electrical properties of $\mathrm{ZnO}$ :In thin films deposited by chemical spray. The aim is to find the optimal solution spray rate to deposit transparent and conductive $\mathrm{ZnO}$ :In thin films.

\section{Experimental}

$\mathrm{ZnO}$ thin films were grown from $100 \mathrm{~mL}$ of spray solution that was pneumatically sprayed onto preheated soda-lime glass substrate $\left(25 \times 25 \times 1 \mathrm{~mm}^{3}\right)$. The chemical spray pyrolysis (CSP) setup is described elsewhere [23]. The spray solution consisted of $\mathrm{Zn}\left(\mathrm{CH}_{3} \mathrm{COO}\right)_{2} \cdot 2 \mathrm{H}_{2} \mathrm{O}$ (Merck, analytical grade, $99.5 \%$ ), dissolved in a mixture of deionised water and isopropyl alcohol $(2: 3$ by volume $)$ with $\mathrm{Zn}\left(\mathrm{CH}_{3} \mathrm{COO}\right)_{2}$ concentration of $0.2 \mathrm{~mol} / \mathrm{L}$. To avoid the precipitation of zinc hydroxide, a few drops of acetic acid were added to the spray solution. As a doping agent, indium(III)chloride $\left(\mathrm{InCl}_{3}\right)$ was added to the spray solution with an indium to zinc atomic ratio of $3\left(\left[\mathrm{In}^{3+}\right] /\left[\mathrm{Zn}^{2+}\right]=3\right.$ at.\%). Compressed air (flow rate $8 \mathrm{~L} / \mathrm{min}$ ) was used as the carrier gas. The glass substrate was washed with soapy water, rinsed with deionised water, and cleaned ultrasonically in ethanol. After cleaning, the substrate was dried using compressed air and placed onto a hot plate. According to the results of our previous study [12], a film growth temperature of $400^{\circ} \mathrm{C}$ was chosen as optimal and kept constant within $\pm 5^{\circ} \mathrm{C}$ throughout the experiments using a feedback control system for the heater. The solution spray rate was varied from $0.5 \mathrm{~mL} / \mathrm{min}$ to $6.7 \mathrm{~mL} / \mathrm{min}$. We verified that the solution spray rate has no effect on the growth temperature.

For a comparison, films with spray rates of $0.35 \mathrm{~mL} / \mathrm{min}$, $0.5 \mathrm{~mL} / \mathrm{min}$, and $1.5 \mathrm{~mL} / \mathrm{min}$ were grown from $150 \mathrm{~mL}$ of spray solution on a soda-lime glass substrate to obtain films with comparable thicknesses throughout the solution spray rate range.

The structure of the films was characterised by X-ray diffraction (XRD) using a Rigaku Ultima IV diffractometer with monochromatic $\mathrm{Cu} \mathrm{K} \alpha$ radiation $(\lambda=1.5406 \AA)$, a tube voltage of $40 \mathrm{kV}$, and a current of $40 \mathrm{~mA}$ using a $\mathrm{D} /$ teX Ultra silicon strip detector. The crystallite size was

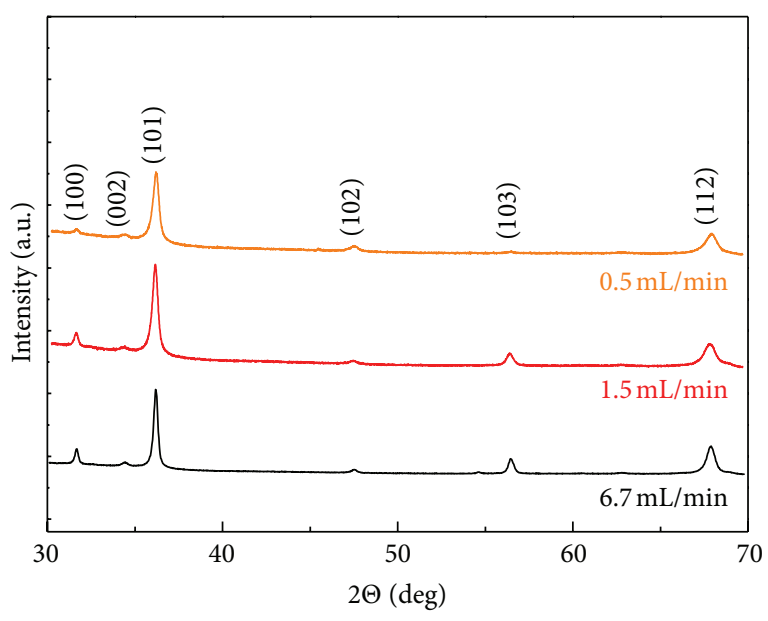

FIGURE 1: X-ray diffraction patterns of $\mathrm{ZnO}$ :In thin films deposited from $100 \mathrm{~mL}$ of spray solution at solution spray rates of $0.5 \mathrm{~mL} / \mathrm{min}$, $1.5 \mathrm{~mL} / \mathrm{min}$, and $6.7 \mathrm{~mL} / \mathrm{min}$.

calculated by the Debye-Scherrer method from the FWHM (full width at half maximum) of the (101) reflection of $\mathrm{ZnO}$. The surface morphology of the films was characterised by scanning electron microscopy (SEM) and atomic force microscopy (AFM). SEM was performed with a Zeiss EVOMA15 microscope at magnifications of 25000x and 50000x. AFM was performed on NT-MDT Solver 47 Pro system in tapping mode. The samples were studied over a $2 \times 2 \mu \mathrm{m}^{2}$ area. The grain sizes estimated from the SEM images were comparable to those measured with the AFM. The surface roughness analysis was performed according to the ISO $4287 / 1$ standard. The root mean square (RMS) roughness was calculated over a $3 \times 3 \mu \mathrm{m}^{2}$ scanned surface area with an accuracy of $\pm 0.5 \mathrm{~nm}$. Image analysis (IA) was achieved using the Media Cybernetics Image-Pro 7 analysing system. The specular UV-VIS-NIR transmittance was recorded in the wavelength range of $350-2500 \mathrm{~nm}$ with Jasco V670 spectrophotometer. The film thickness was calculated using the Spectra Manager software (version 2.02.00) by analysing the interference in the transmittance spectra. The film thickness calculated from the optical spectra is in good agreement (less than $\pm 10 \%$ variance) with that obtained from the SEM images. The elemental composition of the thin films was evaluated from four different $20 \times 20 \mu \mathrm{m}^{2}$ areas on the film using energy dispersive X-ray (EDX) analysis with an Oxford Instruments INCA at an accelerating voltage of $7 \mathrm{kV}$. The electrical properties of the thin films (resistivity, charge carrier concentration, and mobility) were measured at room temperature using MMR's Variable Temperature Hall System supplied with Hall, Van der Pauw Controller H-50. The contact material used for the Van der Pauw and Hall measurements was graphite.

\section{Results and Discussion}

3.1. Structural Properties. The X-ray diffraction patterns of $\mathrm{ZnO}$ :In thin films deposited at various solution spray rates at $400^{\circ} \mathrm{C}$ are presented in Figure 1 . All of the determined 
TABLE 1: The effect of the solution spray rate on the sprayed ZnO:In film thickness $(t)$, crystallite size $(d)$, average grain size $(D)$, electrical resistivity $(\rho)$, main carrier mobility $(\mu)$, carrier concentration $(n)$, and optical band gap $\left(E_{g}\right)$. Soda-lime and borosilicate glasses are designated as Na-gl and B-gl, respectively.

\begin{tabular}{cccccccccc}
\hline Spray rate, $\mathrm{mL} / \mathrm{min}$ & $V, \mathrm{~mL}$ & Substrate & $t, \mathrm{~nm}$ & $d, \mathrm{~nm}$ & $D, \mathrm{~nm}$ & $\rho, \Omega \mathrm{cm}$ & $\mu, \mathrm{cm}^{2} / \mathrm{Vs}$ & $n, \mathrm{~cm}^{-3}$ & $E_{g}, \mathrm{eV}$ \\
\hline 0.5 & 100 & Na-gl & 700 & 22 & $\sim 100$ & $6.3 \cdot 10^{-2}$ & 4.4 & $2.3 \cdot 10^{19}$ & 3.28 \\
0.5 & 150 & Na-gl & 1400 & 26 & $\sim 250$ & $3.3 \cdot 10^{-2}$ & 9.2 & $2.1 \cdot 10^{19}$ & 3.24 \\
0.5 & 150 & B-gl & 1350 & 26 & ${ }^{*}$ n.m. & $7.8 \cdot 10^{-2}$ & 3.9 & $2.0 \cdot 10^{19}$ & 3.24 \\
\hline 1.5 & 100 & Na-gl & 900 & 21 & $\sim 120$ & $1.2 \cdot 10^{-2}$ & 7.7 & $6.9 \cdot 10^{19}$ & 3.31 \\
1.5 & 150 & Na-gl & 1400 & 29 & $\sim 250$ & $7.3 \cdot 10^{-3}$ & 11 & $7.6 \cdot 10^{19}$ & 3.27 \\
\hline 3.3 & 100 & Na-gl & 1100 & 34 & $\sim 250$ & $3.7 \cdot 10^{-3}$ & 16 & $1.1 \cdot 10^{20}$ & 3.34 \\
4.7 & 100 & Na-gl & 1100 & 35 & $\sim 250$ & $3.2 \cdot 10^{-3}$ & 15 & $1.4 \cdot 10^{20}$ & 3.36 \\
6.7 & 100 & Na-gl & 1350 & 36 & $\sim 250$ & $4.6 \cdot 10^{-3}$ & 12 & $1.2 \cdot 10^{20}$ & 3.32 \\
\hline
\end{tabular}

*n.m.: not measured.

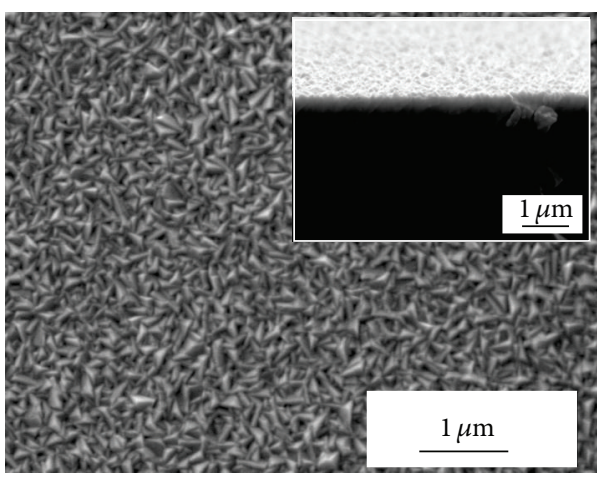

(a)

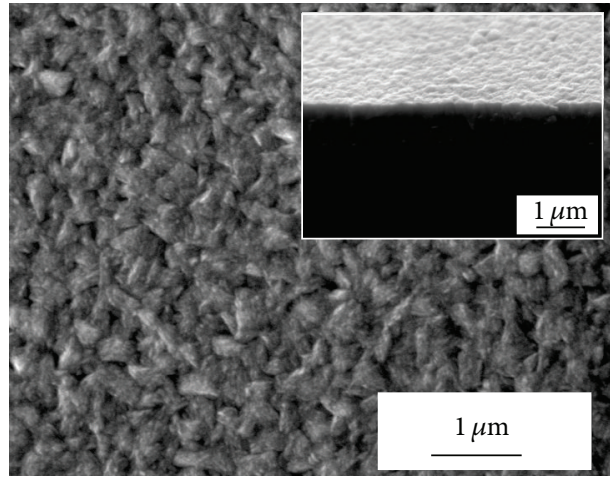

(c)

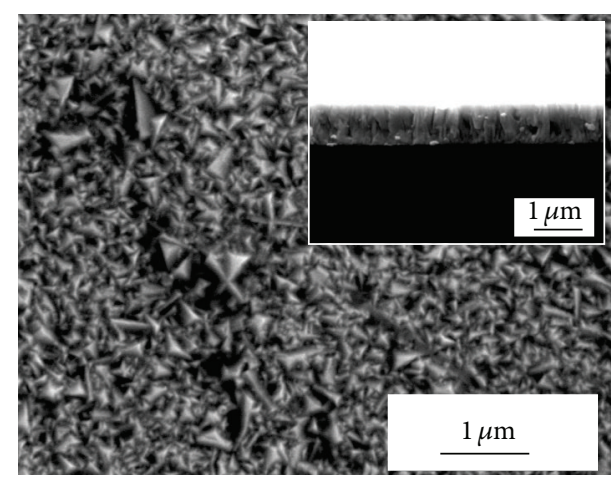

(b)

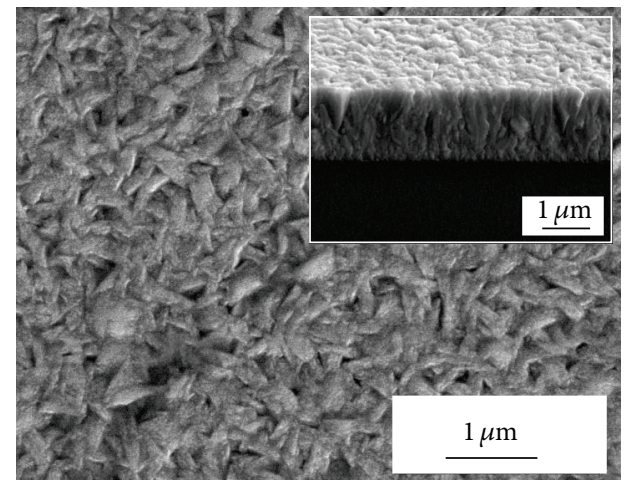

(d)

FIGURE 2: SEM images of ZnO:In thin films deposited from $100 \mathrm{~mL}$ of spray solution at solution spray rates of (a) $0.5 \mathrm{~mL} / \mathrm{min}$, (b) $1.5 \mathrm{~mL} / \mathrm{min}$, (c) $3.3 \mathrm{~mL} / \mathrm{min}$, and (d) $6.7 \mathrm{~mL} / \mathrm{min}$. The cross-sectional views are presented as insets on the surface images.

peaks belong to zincite (PDF card number 01-079-0208) [24]. According to Figure 1, $\mathrm{ZnO}$ :In film is preferably orientated in the (101) plane parallel to the substrate irrespective of the solution spray rate. Solution spray rates below $3 \mathrm{~mL} / \mathrm{min}$ lead to smaller crystallites (average size of $20 \mathrm{~nm}$ ), whereas solution spray rates above $3 \mathrm{~mL} / \mathrm{min}$ result in crystallite sizes of ca. $35 \mathrm{~nm}$ (Table 1).

The microstructure of $\mathrm{ZnO}$ :In films was studied using SEM and AFM. According to the SEM study, sprayed ZnO:In films exhibit a dense inner structure and relatively smooth surface with no cracks or pinholes. The SEM surface and cross-sectional images of $\mathrm{ZnO}$ :In films obtained at various solution spray rates are presented in Figure 2. The surface of the film deposited at the solution spray rate of $0.5 \mathrm{~mL} / \mathrm{min}$ has well-shaped prismatic grains with similar sizes of ca. $100 \mathrm{~nm}$ (Figure 2(a)). The surface of the film grown with the solution flow rate of $1.5 \mathrm{~mL} / \mathrm{min}$ consists of grains that vary in size from $50 \mathrm{~nm}$ to $500 \mathrm{~nm}$ (Figure 2(b)). The surface 


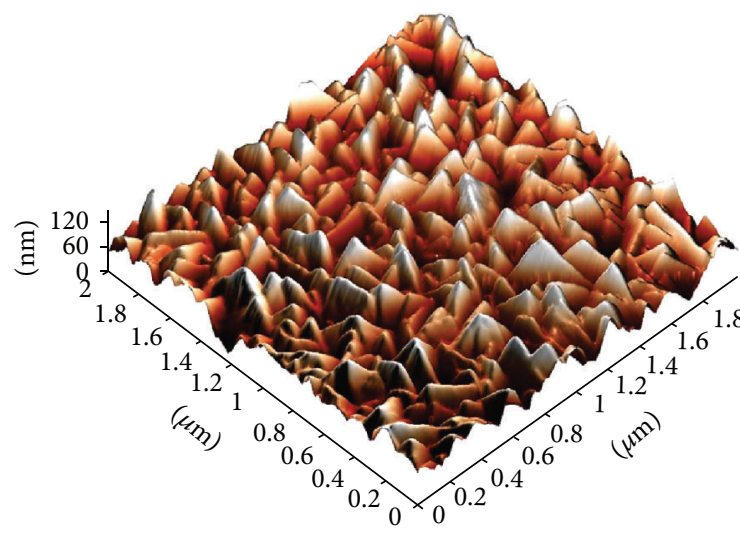

(a) $0.5 \mathrm{~mL} / \mathrm{min}$

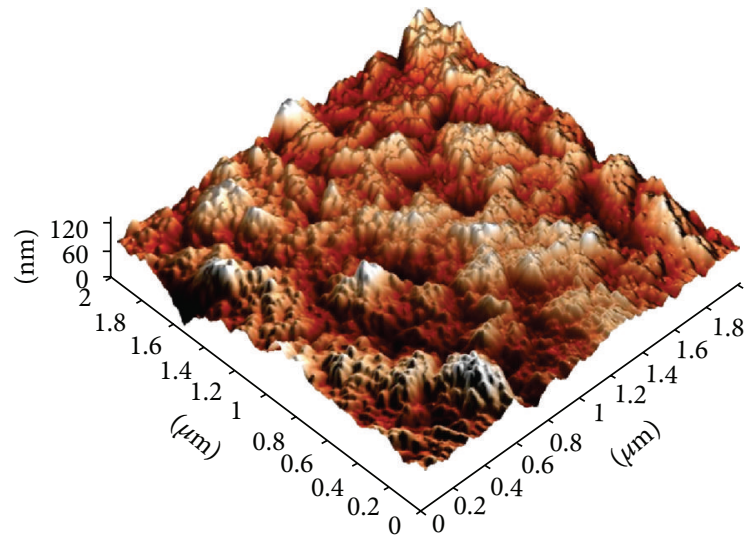

(c) $3.3 \mathrm{~mL} / \mathrm{min}$

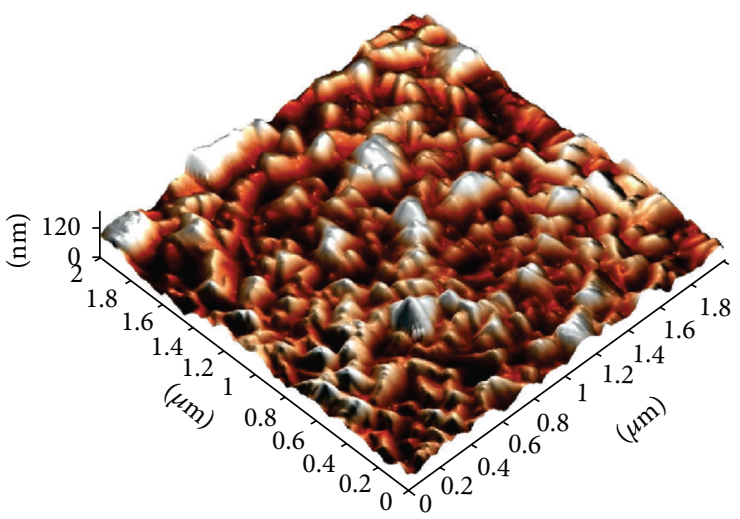

(b) $1.5 \mathrm{~mL} / \mathrm{min}$

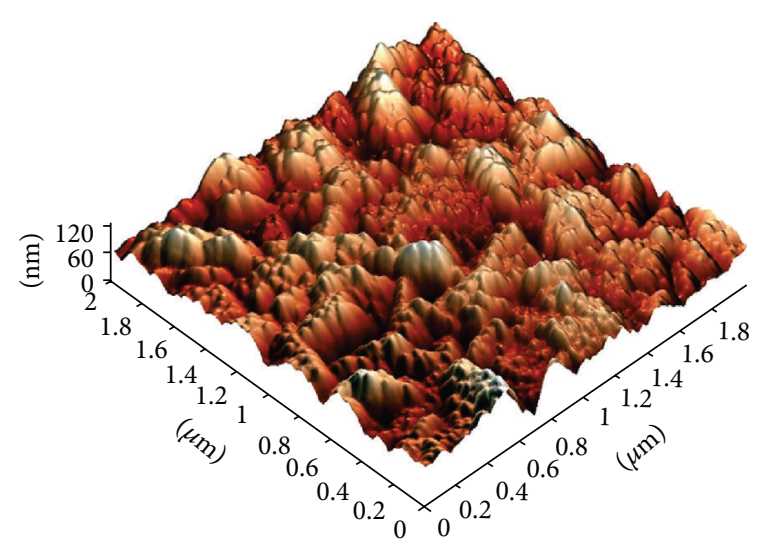

(d) $6.7 \mathrm{~mL} / \mathrm{min}$

FIGURE 3: AFM 3D images of ZnO:In films deposited from $100 \mathrm{~mL}$ of spray solution with solution flow rates of (a) $0.5 \mathrm{~mL} / \mathrm{min}$, (b) $1.5 \mathrm{~mL} / \mathrm{min}$, (c) $3.3 \mathrm{~mL} / \mathrm{min}$, and $6.7 \mathrm{~mL} / \mathrm{min}(\mathrm{d})$. AFM images are of a $2 \times 2 \mu \mathrm{m}^{2}$ area.

structure of the film deposited with the solution spray rate of $3.3 \mathrm{~mL} / \mathrm{min}$ is a network of interweaving grains (size of ca. $250 \mathrm{~nm}$ ) resembling canvas or burlap (see Figure 2(c)). Further increase in the solution spray rate to $6.7 \mathrm{~mL} / \mathrm{min}$ has a minor effect on the surface of $\mathrm{ZnO}$ :In thin film (Figure 2(d)).

The surface morphology of the $\mathrm{ZnO}$ :In films deposited at different solution spray rates was also characterised by AFM using images acquired over a $2 \times 2 \mu \mathrm{m}^{2}$ area (Figure 3 ). The AFM images reveal that the solution spray rate has a strong effect on the surface morphology. The surface of the ZnO:In film obtained at a solution spray rate of $0.5 \mathrm{~mL} / \mathrm{min}$ (Figure 3(a)) consists of well-shaped pyramidal grains with sharp edges and tip. The mean grain size is ca. $100 \mathrm{~nm}$ and the grain aspect ratio (the ratio of the major axis length to the minor axis length of an equiareal ellipse) is ca. 2.0. For the $\mathrm{ZnO}: \mathrm{In}$ film with solution spray rate of $1.5 \mathrm{~mL} / \mathrm{min}$, the peaks and edges of the grains are rounded (Figure 3(b)), and the grain size varied from $70 \mathrm{~nm}$ to $200 \mathrm{~nm}$ (Figure 3(b)). According to the SEM image (Figure 2(b)), some of the grains had a diameter of ca. $500 \mathrm{~nm}$. According to the AFM study, the mean grain size is ca. $120 \mathrm{~nm}$ and the aspect ratio of the grains is ca. 1.7. In contrast, the $\mathrm{ZnO}$ :In films prepared at solution spray rates of $3.3 \mathrm{~mL} / \mathrm{min}$ and above have more complex surface structure (Figures 3(c) and 3(d)).
Using the solution spray rate of $3.3 \mathrm{~mL} / \mathrm{min}$, the film surface (Figure 3(c)) shows a fine-grain structure on top of grains with the size of ca. $200-250 \mathrm{~nm}$ and an aspect ratio of ca. 1.6, forming a double-layer surface. The fine-grain layer is composed of particles with an average diameter of ca. $40 \mathrm{~nm}$. The surface structure of the film deposited at a solution spray rate of $6.7 \mathrm{~mL} / \mathrm{min}$ (Figure $3(\mathrm{~d})$ ) is similar to that prepared at $3.3 \mathrm{~mL} / \mathrm{min}$ (Figure $3(\mathrm{c})$ ). The ca. $200-300 \mathrm{~nm}$ sized grains are covered by individually distinct particles with an average diameter of ca. $50 \mathrm{~nm}$ (Figure 3(d)).

Interestingly, the RMS roughness was ca. $20 \mathrm{~nm}$ for all sprayed ZnO:In films independent of solution spray rate and surface morphology. This RMS is similar to that reported by Dedova et al. [10] for sprayed ZnO:In films.

AFM study showed that the grain size increases with increasing solution spray rate. It is generally recognised that large grains are formed due to the recrystallisation of smaller grains. An extra phase on the grain boundaries may inhibit the growth of grains. This problem will be discussed in more detail in Section 3.2.

3.2. Electrical Properties. The resistivity, carrier concentration, and mobility of $\mathrm{ZnO}$ :In thin films dependent on the solution spray rate are presented in Figure 4. The films 


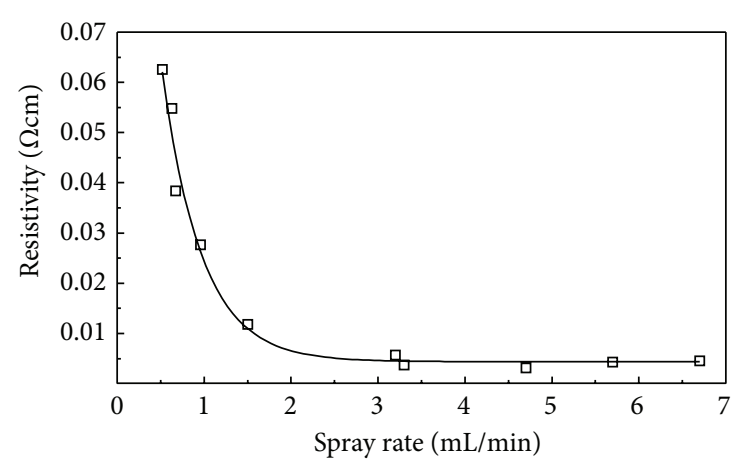

(a)

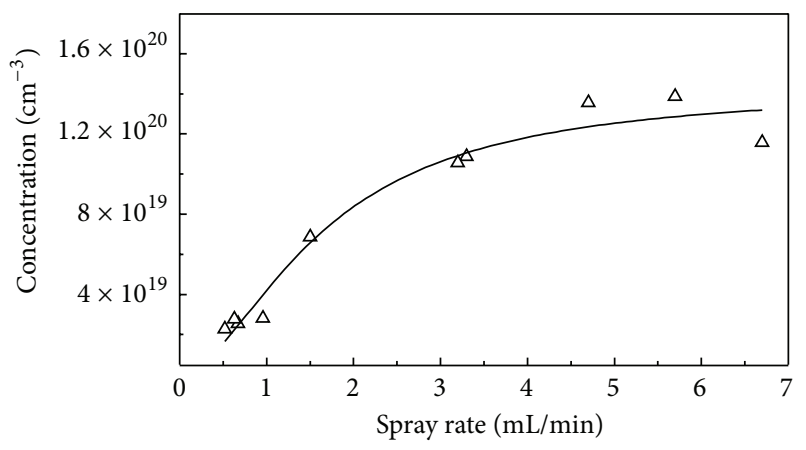

(b)

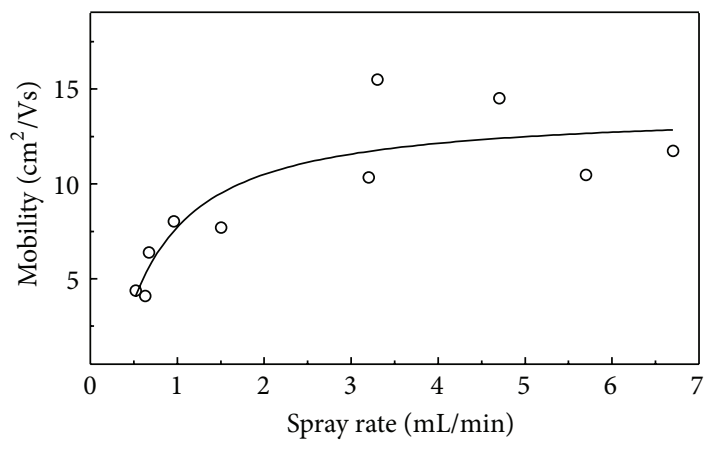

(c)

Figure 4: Resistivity ( $\square$ ), carrier concentration $(\Delta)$, and carrier mobility (o) of ZnO:In thin films deposited from $100 \mathrm{~mL}$ of spray solution at solution spray rates of $0.5-6.7 \mathrm{~mL} / \mathrm{min}$.

presented in Figure 4 are sprayed from $100 \mathrm{~mL}$ of spray solution. The resistivity of the sprayed $\mathrm{ZnO}$ :In films decreases from ca. $6.3 \cdot 10^{-2} \Omega \mathrm{cm}$ to $3.7 \cdot 10^{-3} \Omega \mathrm{cm}$ while increasing the solution spray rate from $0.5 \mathrm{~mL} / \mathrm{min}$ to $3.3 \mathrm{~mL} / \mathrm{min}$, respectively (Figure 4 and Table 1). Increasing the solution spray rate from $0.5 \mathrm{~mL} / \mathrm{min}$ to $3.3 \mathrm{~mL} / \mathrm{min}$ increases the carrier concentration from $2.3 \cdot 10^{19} \mathrm{~cm}^{-3}$ to $1.1 \cdot 10^{20} \mathrm{~cm}^{-3}$ and mobility from $4.4 \mathrm{~cm}^{2} / \mathrm{Vs}$ to $16 \mathrm{~cm}^{2} / \mathrm{Vs}$, respectively. The increase in the carrier mobility with increasing solution spray rate can be ascribed to the increased grain size from 100 to $250 \mathrm{~nm}$ as shown by AFM (Figure 3 and Table 1). This hypothesis is further supported by the following. The positive correlation between the carrier concentration and carrier mobility observed in our films is presented in Figure 5. A similar relation has been noted for $\mathrm{ZnO}: \mathrm{Al}$ films grown by PLD [25], indicating that the conduction mechanism is driven by grain boundary scattering. Further increase in spray rate from $3.3 \mathrm{~mL} / \mathrm{min}$ to $6.7 \mathrm{~mL} / \mathrm{min}$ has minor effect on the electrical properties of $\mathrm{ZnO}$ :In thin films. The films prepared with spray rates above $3 \mathrm{~mL} / \mathrm{min}$ show carrier concentrations around $1 \cdot 10^{20} \mathrm{~cm}^{-3}$ and carrier mobilities in the range of $12-16 \mathrm{~cm}^{2} / \mathrm{Vs}$. A minor rise in resistivity (to 4.6 . $10^{-3} \Omega \mathrm{cm}$ ) in the film deposited at spray rate of $6.7 \mathrm{~mL} / \mathrm{min}$ is attributed to lower carrier mobility of $12 \mathrm{~cm}^{2} /$ Vs. Wienke and Booij [15] reported similar carrier mobility of ca. $14 \mathrm{~cm}^{2} / \mathrm{Vs}$ and concentration of $1.4 \cdot 10^{20} \mathrm{~cm}^{-3}$ for ultrasonically sprayed ZnO:In film.

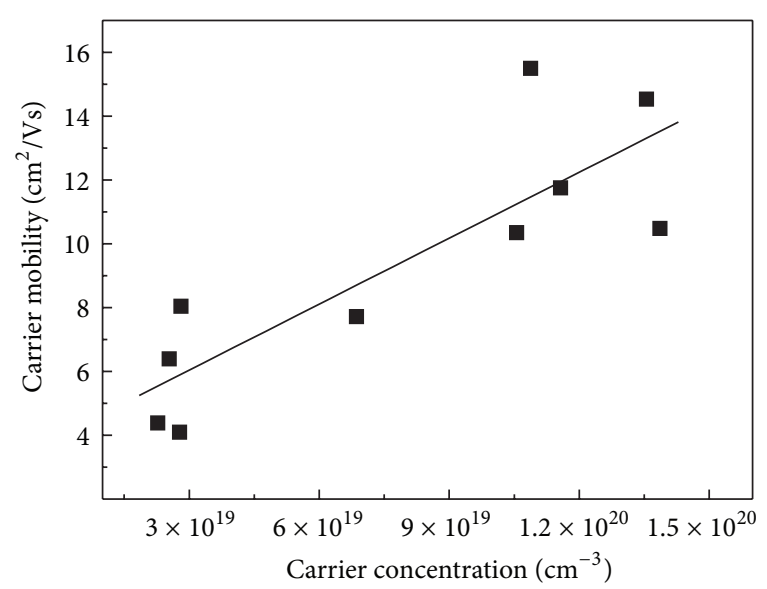

FIgURE 5: Carrier mobility versus carrier concentration of $\mathrm{ZnO}$ :In thin films deposited from $100 \mathrm{~mL}$ of spray solution at solution spray rates of $0.5-6.7 \mathrm{~mL} / \mathrm{min}$.

The films grown with the spray rates of $0.5-1.5 \mathrm{~mL} / \mathrm{min}$ show carrier mobilities of $4.4-7.7 \mathrm{~cm}^{2} / \mathrm{Vs}$ that is up to three times lower than recorded for the films grown with the spray rates above $3 \mathrm{~mL} / \mathrm{min}$ (Figure 4 , Table 1 ). It is known that the carrier mobility in the film is thickness and grain size dependent [26]. To prepare films with comparable thicknesses, the $\mathrm{ZnO}: \mathrm{In}$ films with spray rates of $0.5 \mathrm{~mL} / \mathrm{min}$ and $1.5 \mathrm{~mL} / \mathrm{min}$ were deposited from $150 \mathrm{~mL}$ of spray solution and as a result, 


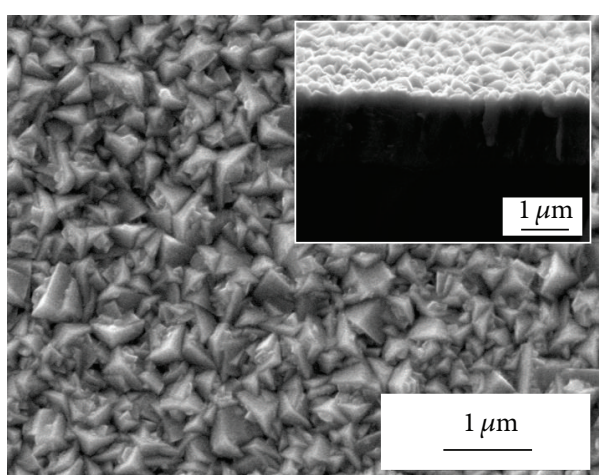

(a)

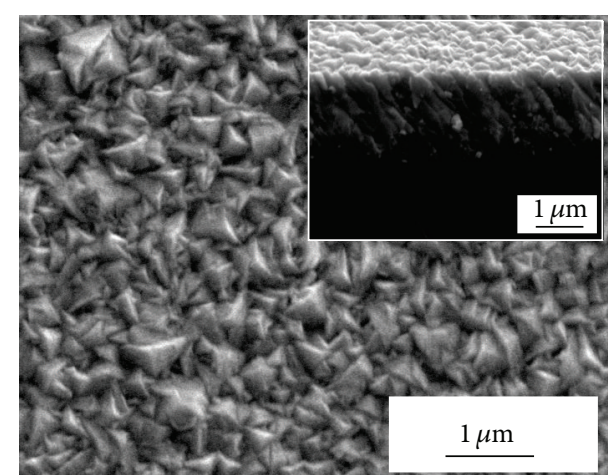

(b)

FIGURE 6: SEM images of ZnO:In thin films deposited from $150 \mathrm{~mL}$ of spray solution at solution spray rates of (a) $0.5 \mathrm{~mL} / \mathrm{min}$, and (b) $1.5 \mathrm{~mL} / \mathrm{min}$. The cross-sectional views are presented as insets on the surface images.

films with thicknesses of ca. $1400 \mathrm{~nm}$ were grown (Table 1). According to SEM images in Figure 6, the shape of the grains in the thicker films is similar to that reported for the thinner films with spray rates of $0.5 \mathrm{~mL} / \mathrm{min}$ and $1.5 \mathrm{~mL} / \mathrm{min}$ in Section 3.1 (Figures 2(a) and 2(b)). The grain sizes of the thicker films with spray rates of $0.5-1.5 \mathrm{~mL} / \mathrm{min}$ were estimated from SEM images (Figure 6). The grain size of the thicker films is ca. 2 times higher when compared to the thinner films (Figures 2(a) and 2(b)). Thus, larger grains (size of ca. $250 \mathrm{~nm}$ ) were obtained in thicker films and that is in accordance with the literature $[9,27,28]$. The carrier mobilities increased with the film thickness from $4.4 \mathrm{~cm}^{2} / \mathrm{Vs}$ to $9.2 \mathrm{~cm}^{2} / \mathrm{Vs}$ and from $7.7 \mathrm{~cm}^{2} / \mathrm{Vs}$ to $11 \mathrm{~cm}^{2} / \mathrm{Vs}$ for films deposited at $0.5 \mathrm{~mL} / \mathrm{min}$ and $1.5 \mathrm{~mL} / \mathrm{min}$, respectively. Still, the mobilities in the films deposited at spray rates of 0.5$1.5 \mathrm{~mL} / \mathrm{min}$ are slightly lower than in the films grown with solution spray rates above $3 \mathrm{~mL} / \mathrm{min}$ regardless of comparable thicknesses (Table 1). The decrease could be due to the larger grain size distribution $(75-700 \mathrm{~nm})$ in the film with spray rate of $0.5 \mathrm{~mL} / \mathrm{min}$ (Figure $6(\mathrm{a})$ ) compared to the film with spray rate of $3.3 \mathrm{~mL} / \mathrm{min}(200-300 \mathrm{~nm}$ ) (Figure $2(\mathrm{c})$ ).

It can be seen from Table 1 that carrier concentration depends on the solution spray rate independent of the film thickness. The carrier concentration of ca. $2 \cdot 10^{19} \mathrm{~cm}^{-3}$ in film grown at $0.5 \mathrm{~mL} / \mathrm{min}$ is ca. 10 times lower than in films with solution spray rate above $3 \mathrm{~mL} / \mathrm{min}\left(\mathrm{ca} .1 \cdot 10^{20} \mathrm{~cm}^{-3}\right)$. Moreover, a ZnO:In film with thickness of $1400 \mathrm{~nm}$ was grown with solution spray rate of $0.35 \mathrm{~mL} / \mathrm{min}$ and the carrier concentration of the mentioned film was $6 \cdot 10^{18} \mathrm{~cm}^{-3}$. As the carrier concentration depends on the doping level $[6,8,15]$ then it is possible that part of the indium was not incorporated into the $\mathrm{ZnO}$ lattice at lower solution spray rates.

It could be speculated that part of the dopant source might have left the system at slow spray rates due to relatively high $\mathrm{InCl}_{3}$ vapour pressure of ca. $1.0 \mathrm{kPa}$ at $400^{\circ} \mathrm{C}$ [29]. For this reason, the elemental composition of the films obtained with different spray rates was studied. According to EDX, the films deposited at different solution spray rates have similar elemental compositions (Table 2). Thus, the $[\mathrm{In}] /[\mathrm{Zn}]$ ratio in the film is constant at varied spray rates. As the EDX measurements were performed using factory-defined
TABLE 2: Elemental composition (in at.\%) of $\mathrm{ZnO}$ :In thin films deposited at solution spray rates of $0.5 \mathrm{~mL} / \mathrm{min}$ and $3.2 \mathrm{~mL} / \mathrm{min}$ according to EDX.

\begin{tabular}{cccc}
\hline Solution spray rate, $\mathrm{mL} / \mathrm{min}$ & $\mathrm{Zn}$ & $\mathrm{O}$ & $\mathrm{In}$ \\
\hline 0.5 & 43.4 & 54.4 & 2.2 \\
3.2 & 43.3 & 54.7 & 2.0 \\
\hline
\end{tabular}

standards only, the atomic percentages of the elements are not absolute values. However, EDX confirms that there is no loss of the dopant source or that the loss is similar at all solution spray rates used.

Another cause for lower electron concentration while using low solution spray rates can be the diffusion of $\mathrm{Na}$ to the $\mathrm{ZnO}$ film from the soda-lime glass substrate at $400^{\circ} \mathrm{C}$ during long spray process [30]. In that case, Na could create defects that reduce the concentration of free electrons. Unfortunately, EDX cannot be used to detect $\mathrm{Na}$ due to the overlapping peaks of $\mathrm{Zn}$ and $\mathrm{Na}$. To overcome this problem, a thicker $\mathrm{ZnO}$ :In film (from $150 \mathrm{~mL}$ ) with thickness comparable to that on a soda-lime glass was deposited onto a borosilicate substrate at $0.5 \mathrm{~mL} / \mathrm{min}$. Film with thickness of ca. $1350 \mathrm{~nm}$ has a resistivity of $7.8 \cdot 10^{-2} \Omega \mathrm{cm}$, carrier mobility of $3.9 \mathrm{~cm}^{2} / \mathrm{Vs}$, and concentration of $2.0 \cdot 10^{19} \mathrm{~cm}^{-3}$ (see Table 1). The carrier concentrations of $\mathrm{ZnO}$ :In films on soda-lime and borosilicate glass substrate are comparable and thus the diffusion of $\mathrm{Na}$ is not responsible for the lower concentration of electrons in the films with low spray rates.

As there is no difference in the dopant concentration in the films deposited at different solution spray rates and the diffusion of sodium is not the case, the lower carrier concentration in the films with lower solution spray rates could be due to the failing of In incorporation into the $\mathrm{ZnO}$ lattice due to the oxidation of indium source. The study of ZnO:In films structural properties supports this hypothesis, as an extra phase on the grain boundaries inhibited the grain growth at low solution spray rates (see Section 3.1).

3.3. Optical Properties. The optical transmittance spectra of the $\mathrm{ZnO}$ :In films grown from $100 \mathrm{~mL}$ of spray solution using 


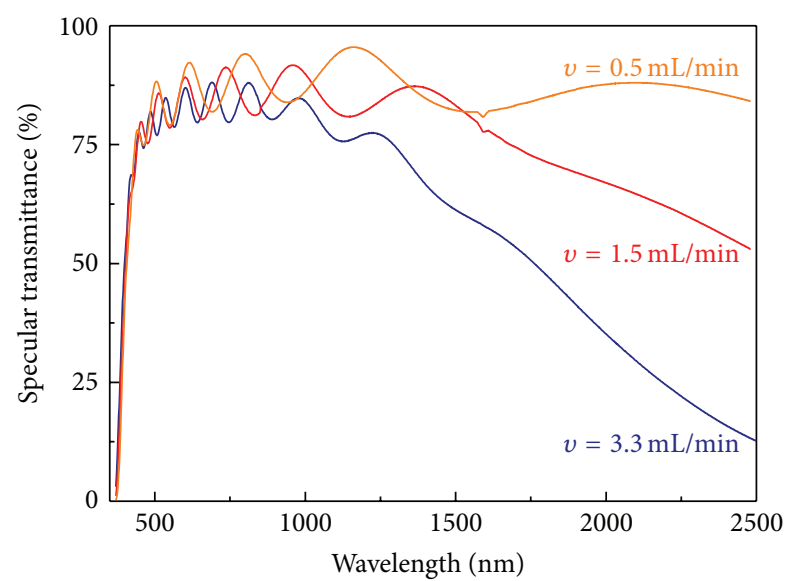

FIgURE 7: Specular transmittance of $\mathrm{ZnO}$ :In thin films deposited from $100 \mathrm{~mL}$ of spray solution at solution spray rates of $0.5 \mathrm{~mL} / \mathrm{min}$, $1.5 \mathrm{~mL} / \mathrm{min}$, and $3.3 \mathrm{~mL} / \mathrm{min}$.

various solution spray rates are presented in Figure 7. In the visible light region, the $\mathrm{ZnO}$ :In thin films show specular transmittance above $75 \%$ irrespective of the solution spray rate.

For the film prepared at $0.5 \mathrm{~mL} / \mathrm{min}$ or lower, the transmittance in the near infrared region (NIR) is comparable to that in UV-VIS region. The increase in solution spray rate decreases film transmittance in the NIR region and the lowest transmittance is recorded for the film with solution spray rate of $3.3 \mathrm{~mL} / \mathrm{min}$. The decrease in the optical transmittance in the NIR spectral region corresponds to the increased concentration of carriers in the films sprayed at higher solution spray rates (Table 1). According to the literature, the decrease in the transmittance of TCO films in NIR spectral region is caused by the free carrier absorption [31-33]. This has been recorded for conductive $\mathrm{ZnO}$ films with electron concentrations of $3 \cdot 10^{20} \mathrm{~cm}^{-3}$ and $6 \cdot 10^{20} \mathrm{~cm}^{-3}$ deposited by ion-layer gas reaction spray [31] and PLD [32], respectively.

The optical band gap of the films is determined from the transmittance spectra. The optical band gap values were determined from the commonly used equation

$$
\alpha h \nu=A \cdot\left(h v-E_{g}\right)^{1 / n},
$$

where $A$ is the parameter that does not depend on the photon energy, $h$ is the Planck constant, $E_{g}$ is the band gap energy, $h v$ is the incident photon energy, and $1 / n$ is an exponent that depends on the nature of the optical transition $(n=0.5$ for direct transition). The determination of $E_{g}$ from $(\alpha h \nu)^{2}$ versus the $h v$ plot is shown in Figure 8 and the $E_{g}$ values of $\mathrm{ZnO}$ :In films depending on the solution spray rate are given in Table 1. The ZnO:In film band gap increases from $3.24 \mathrm{eV}$ to $3.36 \mathrm{eV}$ as the solution spray rate increases from $0.5 \mathrm{~mL} / \mathrm{min}$ to $4.7 \mathrm{~mL} / \mathrm{min}$, respectively. The increase in the band gap is in accordance with the increase in the carrier concentration (Table 1) and can be explained by the BursteinMoss effect [33]. Thus, we have achieved a good agreement with the results of similar studies on $\mathrm{ZnO}[11,13,15,25,33]$.

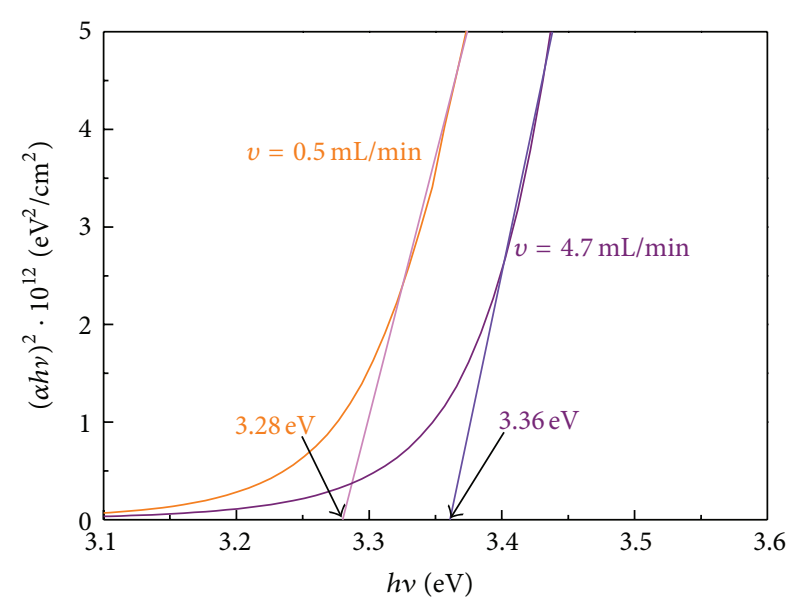

FIGURE 8: Graphical determination of direct optical band gap of $\mathrm{ZnO}$ :In thin films deposited from $100 \mathrm{~mL}$ of spray solution with solution spray rates of $0.5 \mathrm{~mL} / \mathrm{min}$ and $4.7 \mathrm{~mL} / \mathrm{min}$.

\section{Conclusions}

At constant spray solution volume, an increase in the solution spray rate results in thicker $\mathrm{ZnO}$ :In films with larger crystallites and grains; also the surface morphology and electrical conductivity are affected. The grains in the film with spray rate of $1.5 \mathrm{~mL} / \mathrm{min}$ are roundish when compared to the sharp-edged grains in the film with spray rate of $0.5 \mathrm{~mL} / \mathrm{min}$. The surface of the films with spray rate above $3 \mathrm{~mL} / \mathrm{min}$ is composed of canvas-resembling grains (size ca. $250 \mathrm{~nm}$ ) covered with particles with the size of ca. $40-50 \mathrm{~nm}$. Increasing the spray rate from $0.5 \mathrm{~mL} / \mathrm{min}$ to $3.3 \mathrm{~mL} / \mathrm{min}$ decreases the electrical resistivity from $6.3 \cdot 10^{-2} \Omega \mathrm{cm}$ to $3.7 \cdot 10^{-3} \Omega \mathrm{cm}$ as the carrier concentration increases from $2.3 \cdot 10^{19} \mathrm{~cm}^{-3}$ to $1.1 \cdot 10^{20} \mathrm{~cm}^{-3}$ and mobility from $4.4 \mathrm{~cm}^{2} / \mathrm{Vs}$ to $16 \mathrm{~cm}^{2} / \mathrm{Vs}$, respectively.

To obtain films with comparable thicknesses throughout the solution spray rate range, more spray solution has to be used for films deposited at $1.5 \mathrm{~mL} / \mathrm{min}$ and below. An increase in film thickness from $700 \mathrm{~nm}$ to $1400 \mathrm{~nm}$ and in grain size from $100 \mathrm{~nm}$ to ca. $250 \mathrm{~nm}$ increases the carrier mobility from $4.4 \mathrm{~cm}^{2} / \mathrm{Vs}$ to $9.2 \mathrm{~cm}^{2} / \mathrm{Vs}$ and from $7.7 \mathrm{~cm}^{2} / \mathrm{Vs}$ to $11 \mathrm{~cm}^{2} / \mathrm{Vs}$ for films deposited at $0.5 \mathrm{~mL} / \mathrm{min}$ and $1.5 \mathrm{~mL} / \mathrm{min}$, respectively. Independent of the similar film thicknesses and the mean grain sizes, the mobilities in the slowly grown films are lower than in films with spray rate above $3 \mathrm{~mL} / \mathrm{min}$. Higher spray rates lead to higher carrier concentrations: spray rates of $0.5,1.5$, and $3.3 \mathrm{~mL} / \mathrm{min}$ result in carrier concentrations of ca. $2 \cdot 10^{19}, 7 \cdot 10^{19}$, and $1 \cdot 10^{20} \mathrm{~cm}^{-3}$, respectively. The decreased carrier concentrations characteristic of the films with lower spray rates could be due to the oxidation of indium source that prevents indium from acting as the dopant in $\mathrm{ZnO}$. Sprayed $\mathrm{ZnO}$ :In films with thickness of 1.1$1.4 \mu \mathrm{m}$ transmit $75-80 \%$ of visible light. A decrease of the transmittance in NIR spectral region and an increase in band gap is characteristic of films with higher spray rate and corresponds to the increased carrier concentration in these films. 
This study shows that the solution spray rate is an important technological parameter controlling the film thickness, morphology, grain size, optical properties, and electrical conductivity of the sprayed $\mathrm{ZnO}$ :In films. Still, the optimal spray rate should be determined for every setup to obtain films with properties required for a transparent and conductive material.

\section{Conflict of Interests}

The authors declare that they have no conflict of interests in the submitted paper.

\section{Acknowledgments}

Financing by the Estonian Ministry of Education and Research under Project SF0140092s08, the Estonian Science Foundation (ETF9081), and the European Regional Development Fund (Centre of Excellence "Mesosystems: Theory and Applications" TK114 and Project 3.2.1101.12-0023) is gratefully acknowledged. This work has been partially supported by the graduate school "Functional materials and technologies" receiving funding from the European Social Fund under Project 1.2.0401.09-0079 in Estonia.

\section{References}

[1] N. H. Nickel and E. Terukov, Zinc Oxide-A Material For Micro- and Optoelectronic Applications, Springer, Dordrecht, The Netherlands, 2005.

[2] L. Niinistö, J. Päiväsaari, J. Niinistö, M. Putkonen, and M. Nieminen, "Advanced electronic and optoelectronic materials by Atomic Layer Deposition: an overview with special emphasis on recent progress in processing of high- $k$ dielectrics and other oxide materials," Physica Status Solidi A, vol. 201, pp. 1443-1452, 2004.

[3] X. M. Li, J. L. Zhao, J. M. Bian, W. D. Yu, and C. Y. Zhang, "Comparison of structural and photoluminescence properties of $\mathrm{ZnO}$ thin films grown by pulsed laser deposition and ultrasonic spray pyrolysis," Thin Solid Films, vol. 515, no. 4, pp. 1763-1766, 2006.

[4] A. Drici, G. Djeteli, G. Tchangbedji et al., "Structured $\mathrm{ZnO}$ thin films grown by chemical bath deposition for photovoltaic applications," Physica Status Solidi A, vol. 201, no. 7, pp. 15281536, 2004.

[5] M. K. Jayaraj, A. Antony, and M. Ramachandran, "Transparent conducting zinc oxide thin film prepared by off-axis rf magnetron sputtering," Bulletin of Materials Science, vol. 25, no. 3, pp. 227-230, 2002.

[6] A. Hafdallah, F. Yanineb, M. S. Aida, and N. Attaf, "In doped $\mathrm{ZnO}$ thin films," Journal of Alloys and Compounds, vol. 509, no. 26, pp. 7267-7270, 2011.

[7] A. R. Babar, P. R. Deshamukh, R. J. Deokate, D. Haranath, C. H. Bhosale, and K. Y. Rajpure, "Gallium doping in transparent conductive $\mathrm{ZnO}$ thin films prepared by chemical spray pyrolysis," Journal of Physics D, vol. 41, no. 13, Article ID 135404, 2008.

[8] M. Krunks, O. Bijakina, V. Mikli, T. Varema, and E. Mellikov, "Zinc oxide thin films by spray pyrolysis method," Physica Scripta, vol. 79, pp. 209-212, 1999.

[9] M. L. Olvera, H. Gómez, and A. Maldonado, "Doping, vacuum annealing, and thickness effect on the physical properties of zinc oxide films deposited by spray pyrolysis," Solar Energy Materials and Solar Cells, vol. 91, no. 15-16, pp. 1449-1453, 2007.

[10] T. Dedova, J. Klauson, C. Badre et al., "Chemical spray deposition of zinc oxide nanostructured layers from zinc acetate solutions," Physica Status Solidi A, vol. 205, no. 10, pp. 23552359, 2008.

[11] T. V. Vimalkumar, N. Poornima, C. Sudha Kartha, and K. P. Vijayakumar, "On tuning the orientation of grains of spray pyrolysed ZnO thin films," Applied Surface Science, vol. 256, no. 20, pp. 6025-6028, 2010.

[12] M. Vent, E. Kärber, T. Unt, A. Mere, and M. Krunks, “The effect of growth temperature and spraying rate on the properties of ZnO:In films," Physica Status Solidi C, vol. 9, pp. 1604-1606, 2012.

[13] A. Maldonado, J. Rodríguez-Baez, and M. L. Olvera, "Physical properties of indium and fluorine codoped zinc oxide thin films deposited by chemical spray," Materials Chemistry and Physics, vol. 129, no. 1-2, pp. 109-115, 2011.

[14] R. Biswal, L. Castañeda, R. Moctezuma, J. Vega-Pérez, M. L. Olvera, and A. Maldonado, "Formation of indium-doped zinc oxide thin films using ultrasonic spray pyrolysis: the importance of the water content in the aerosol solution and the substrate temperature for enhancing electrical transport," Materials, vol. 5, pp. 432-442, 2012.

[15] J. Wienke and A. S. Booij, "ZnO:In deposition by spray pyrolysis-influence of the growth conditions on the electrical and optical properties," Thin Solid Films, vol. 516, no. 14, pp. 45084512, 2008.

[16] J. Ebothé, A. El Hichou, P. Vautrot, and M. Addou, "Flow rate and interface roughness of zinc oxide thin films deposited by spray pyrolysis technique," Journal of Applied Physics, vol. 93, no. 1, pp. 632-640, 2003.

[17] S. Major, A. Banerjee, and K. L. Chopra, "Highly transparent and conducting indium-doped zinc oxide films by spray pyrolysis," Thin Solid Films, vol. 108, no. 3, pp. 333-340, 1983.

[18] K. T. R. Reddy, T. B. S. Reddy, I. Forbes, and R. W. Miles, "Highly oriented and conducting $\mathrm{ZnO}$ :Ga layers grown by chemical spray pyrolysis," Surface and Coatings Technology, vol. 151-152, pp. 110-113, 2002.

[19] M. L. Olvera, A. Maldonado, R. Asomoza, R. Castanedo-Pérez, G. Torres-Delgado, and J. Cañetas-Ortega, "Conductive and transparent $\mathrm{ZnO}$ :Al thin films obtained by chemical spray," Journal of Materials Science, vol. 11, no. 5, pp. 383-387, 2000.

[20] J. Wienke, B. van der Zanden, M. Tijssen, and M. Zeman, "Performance of spray-deposited $\mathrm{ZnO}$ :In layers as front electrodes in thin-film silicon solar cells," Solar Energy Materials and Solar Cells, vol. 92, no. 8, pp. 884-890, 2008.

[21] C. H. Fischer, N. A. Allsop, S. E. Gledhill et al., "The sprayILGAR (ion layer gas reaction) method for the deposition of thin semiconductor layers: process and applications for thin film solar cells," Solar Energy Materials and Solar Cells, vol. 95, no. 6, pp. 1518-1526, 2011.

[22] M. Krunks, E. Kärber, A. Katerski et al., "Extremely thin absorber layer solar cells on zinc oxide nanorods by chemical spray," Solar Energy Materials and Solar Cells, vol. 94, no. 7, pp. 11911195, 2010.

[23] K. Otto, A. Katerski, A. Mere, O. Volobujeva, and M. Krunks, "Spray pyrolysis deposition of indium sulphide thin films," Thin Solid Films, vol. 519, no. 10, pp. 3055-3060, 2011.

[24] "International Centre for Diffraction Data (ICDD)," PDF-2 Release 2008. 
[25] T. Minami, "Transparent conducting oxide semiconductors for transparent electrodes," Semiconductor Science and Technology, vol. 20, no. 4, pp. S35-S44, 2005.

[26] C. E. Benouis, M. Benhaliliba, A. Sanchez Juarez, M. S. Aida, F. Chami, and F. Yakuphanoglu, "The effect of indium doping on structural, electrical conductivity, photoconductivity and density of states properties of $\mathrm{ZnO}$ films," Journal of Alloys and Compounds, vol. 490, no. 1-2, pp. 62-67, 2010.

[27] R. Venkatraman and J. C. Bravman, "Separation of film thickness and grain boundary strengthening effects in $\mathrm{Al}$ thin films on Si," Journal of Materials Research, vol. 7, no. 8, pp. 2040-2048, 1992.

[28] R. M. Keller, S. P. Baker, and E. Arzt, "Quantitative analysis of strengthening mechanisms in thin $\mathrm{Cu}$ films: effects of film thickness, grain size, and passivation," Journal of Materials Research, vol. 13, no. 5, pp. 1307-1317, 1998.

[29] B. Brunetti, V. Piacente, and P. Scardala, "Torsion study on the sublimation process of $\mathrm{InCl}_{3}$," Journal of Chemical and Engineering Data, vol. 43, no. 1, pp. 101-104, 1998.

[30] A. Katerski, A. Mere, V. Kazlauskiene et al., "Surface analysis of spray deposited copper indium disulfide films," Thin Solid Films, vol. 516, no. 20, pp. 7110-7115, 2008.

[31] S. Gledhill, A. Grimm, D. Greiner, W. Bohne, M. Lux-Steiner, and C. H. Fischer, "Doping induced structural and compositional changes in $\mathrm{ZnO}$ spray pyrolysed films and the effects on optical and electrical properties," Thin Solid Films, vol. 519, no. 13, pp. 4293-4298, 2011.

[32] L. Gong, Z. Ye, J. Lu et al., "Highly transparent conductive and near-infrared reflective $\mathrm{ZnO}$ :Al thin films," Vacuum, vol. 84, no. 7, pp. 947-952, 2010.

[33] V. Bhosle, A. Tiwari, and J. Narayan, "Electrical properties of transparent and conducting Ga doped ZnO," Journal of Applied Physics, vol. 100, no. 3, Article ID 033713, 6 pages, 2006. 

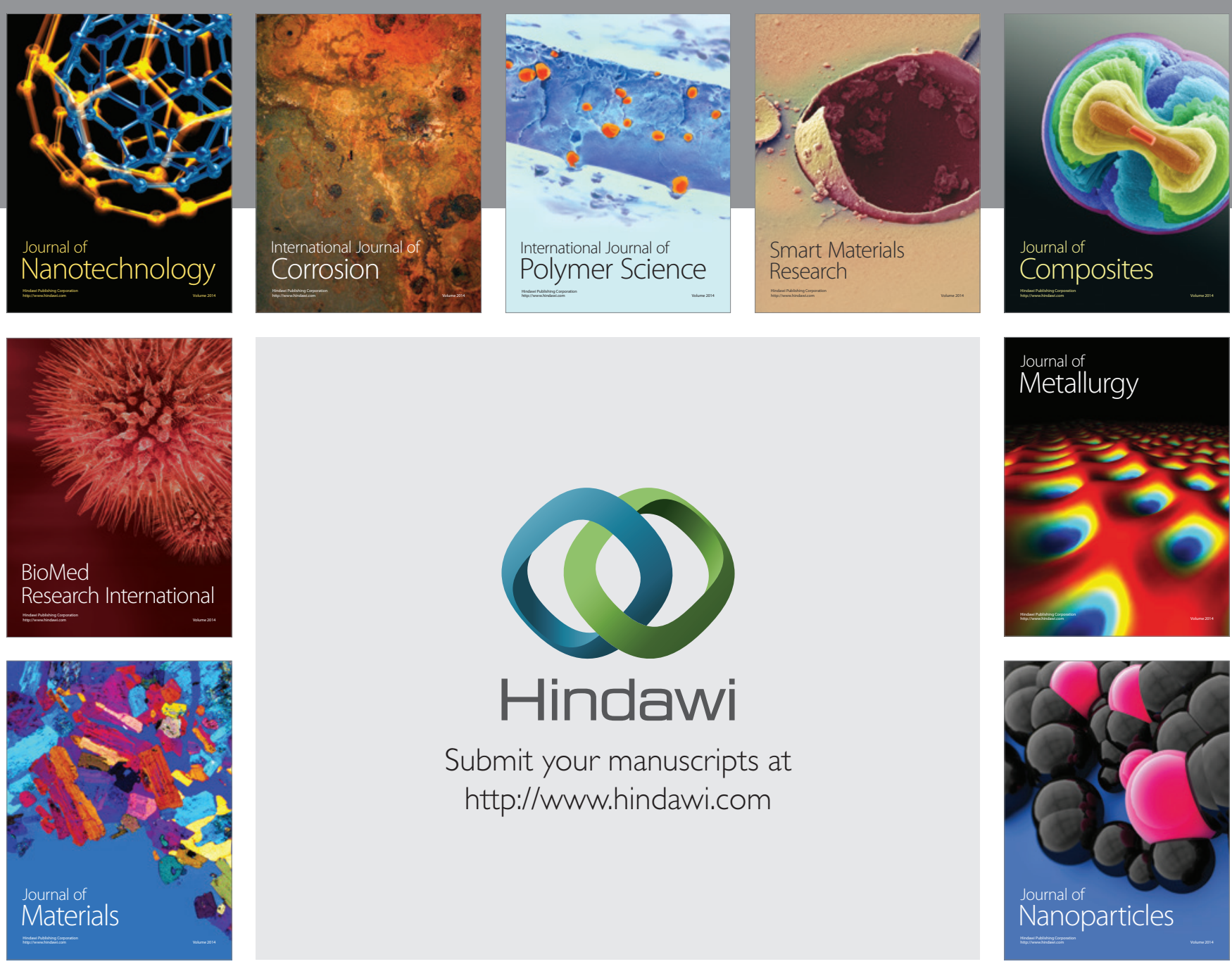

Submit your manuscripts at http://www.hindawi.com
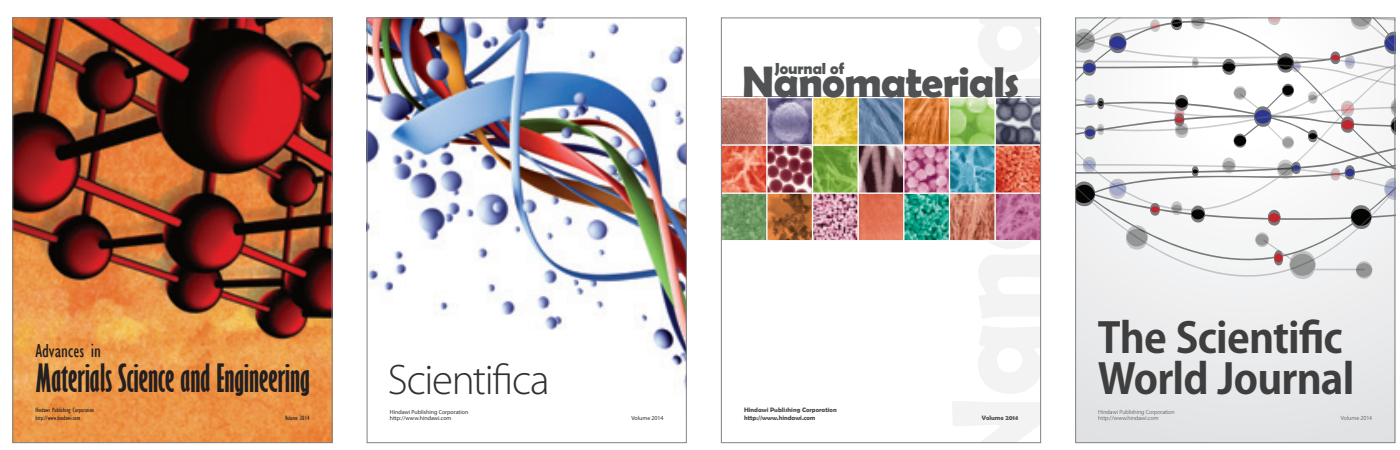

\section{The Scientific World Journal}
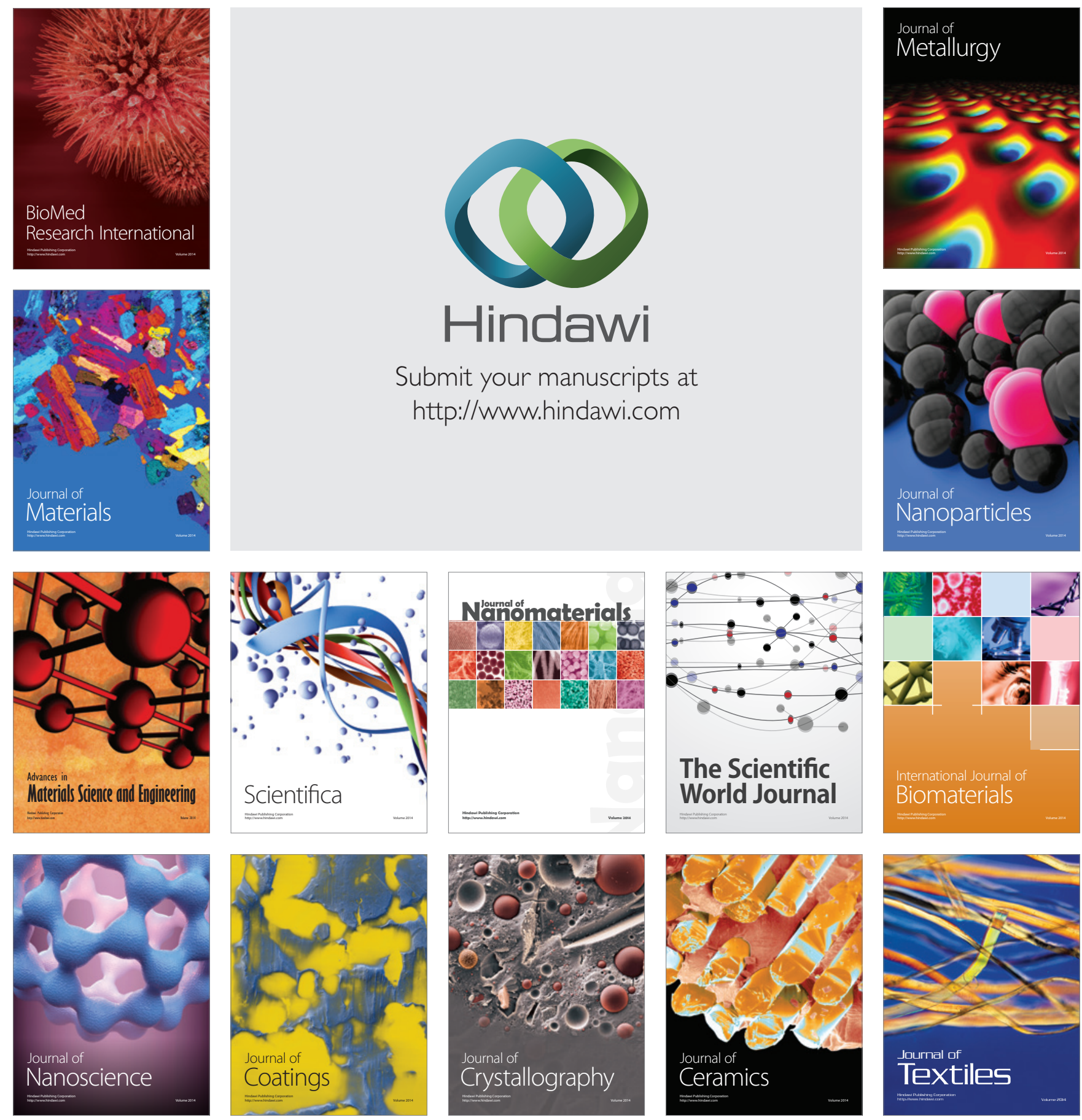